\title{
An Examination of the Causes of Kidnapping and Its Attendant Challenges in Ogun State, Nigeria
}

\author{
Segun Ayotunde Olulowo, Solomon Taiwo Babawale \& \\ Kehinde Michael Anani \\ https://dx.doi.org/10.4314/jrhr.v13i1.7
}

\section{Abstract}

Kidnappers have become thorns in the flesh of citizens and foreigners domicile in Ogun state. The paper examines causes of kidnapping and its consequences, investigates the roles of schools, religion and government in tackling the problem. The paper adopted a descriptive method; questionnaires were administered among Churches in Ogun State. Analysis revealed quest for ransom, revenge, rituals, Poverty, youth's unemployment, and many more. Kidnappings have economic, political, social and psychological impacts. The paper proposed families, schools, religion and government interventions, strengthening the culture of hard work and stepping up of religious ethical teachings.

Keywords: Kidnapping, Religious-Ethics and Crime

\section{Introduction}

The existence of kidnappers has become a thorn in the flesh of many citizens and foreigners domicile in Ogun state, Nigeria. Kidnapping is growing at an extraordinary rate across the State. People's movements to their work places have been hindered by the fear of kidnappers. Kidnapping activities have increased in an overwhelming manner between 2014 and 2017. In Nigeria it was reported that over 2000 people including young Chibok girls, government officials, politicians and kings were subjected to kidnap (Abdulkabir, 2017). Kidnap for ransom is fast becoming a lucrative business motivated by profit 
rather than principle (Briggs, 2001). Thus, the need for alertness, call to order and an overhaul of security institutions in a country where crime precedes security (Zeman et al. 2018; Teivāns-Treinovskis et al. 2018; Kuril 2018). The menace of Kidnapping destabilizes the social frameworks of society by wearing away the sense of security and safety. Its cost could be tangible, intangible, economic, social, physical, psychological, primary and secondary on individual and society at large (Ene, W. R 2018).For instance, in the year 2008 Nigeria was placed sixth on the global kidnap index by an online tourism site (Ujumadu, 2008; Ekpe, 2009).

The report above could serve as an assumption due to lack of accurate statistical data. Also Ekpe, reported that Nigeria recorded 512 cases of kidnapping and 30 dead persons recorded in 2009. The Nigerian police record shows also that in 2009, kidnappers and hostage keepers got N15 million in ransom and about N100 million were collected as ransom in between 2006 - 2009. Kidnapping cases in southern Nigeria have been ravaging daily (Kyrian, 2009). Kidnapping drives away investment, both foreign direct investments and domestic and consequently slows down growth.The fear of who will be the next victim is all in the air, since kidnappers spare no one as far as their motives are achieved. Over the last few years, the wealthy and the income earners have been picked up by kidnappers who only free their victims after payments of ransom. Old people as well as children between the ages of two and five years have been taken hostage. The incident of kidnapping has affected Nigeria's image as a nation abroad. The paper would explore areas of family, educational, governmental and religious intervention in the violent crime process of kidnapping especially to proffer solution that would be both enduring and peace sustaining.

\section{Objectives of the Stud}

The paper will work towards achieving the following objectives: 
1. To examine the causes of kidnapping in Ogun State.

2. Tohighlight the resultant consequences of kidnapping in Ogun State

3. To scrutinize the role of schools, families, the government and the church as a religious organisation, in tackling kidnapping as a social problem in Ogun State.

\section{Statement of the Problem}

The existence of kidnappers has become a thorn in the flesh of many citizens and foreigners domicile in Ogun state, south western Nigeria. Kidnapping is growing at an extra-ordinary rate across the South West geopolitical zone of the Nigeria. People's movements to their working places have been hampered by the fear of kidnappers. The Paper attempt would be to explore areas of education, family, government and religious intervention in the violent crime process of kidnapping especially to proffer solution that would be both enduring and peace sustaining.

\section{Research Questions}

The paper will thus provide answers to the following questions:

1. What are the causes of kidnapping in Ogun State?

2. What are the consequences of kidnapping in Ogun State?

3. What are the roles of the Schools, families, government and church as a religious organisation and socio-religion solutions or policies that could be formulated in tackling kidnapping as a social problem?

\section{Theoretical Framework}

These three theories are very relevant to this paper that set out to evaluates the causes, the Consequences and the dominance of kidnappings in Nigeria: 
1. The Strain Theory: This theory is a sociologically belief that, pressure mounted on an individual by social structures within the society (derived from social factors) such as lack of income or lack of quality education, which some may not have the means to achieve, which eventually put strain on them and may drive an individual to commit crimes such as peddling of drugs, prostitution to make wealth (Wikipedia, 2018). The theory is propounded by Emile Durkheim and was advanced by Merton (1938) and others.

2. Frustration-Aggression Theory: Frustration-Aggression theory was propounded by John Dollard and his team of researchers in 1939. The theory was expanded and modified by Leonard Berkowitz and others in 1962. This theory believes that when individuals or groups are denied what they feel they desire legitimately, they feel disappointed which will lead to frustration and violent behaviour. The violent behaviour will be directed at those they perceive are responsible directly or indirectly for such denial. It also maintains that where expectation does not meet attainment, people tend to confront those they feel are responsible for not attaining the expected issues or benefits. The non-attainment of the expectation leads to anger, frustration and aggressive behaviour or violence. This theory is of the opinion that when youths struggles to go through the rigours of training themselves in schools and eventually come out in flying colours hoping they will get a rewarding job at the end of the day but the jobs are nowhere to be found, and six years after graduation are still been forced to depend on parents that struggle to see them through schools, some might get frustrated and decided to be involved in any crime just to make end meet.

\section{Conceptual Clarification}

Kidnapping: Kidnapping is a universal occurrence that is as old as creation itself. It is a phenomenon that has been in existence since the 
creation of a coordinated human's society. Kidnapping has become widespread in the Nigerian society, having a serious effect on our communal sense of right and wrong. For example, in the year 2008, Nigeria was placed sixth on the global kidnap index by an online tourism site. According to Ekpe, (2009), Nigeria recorded 512 cases of kidnapping and 30 persons were put on record to have died in their kidnappers $^{\text {ee }}$ den that year out of 353 cases recorded throughout 2008. In the same way, Kyrian (2009) also documented that the former Inspector General of Police in Nigeria had noted that, kidnappers and hostage takers got about USD100 million between 2006 and 2009.

Kidnapping is to forcefully seize, take away and unlawful detailing a person against his/her will. It is a common offence against the law and the victim. It is places restriction on the victims' liberty which is not in tandem with the provision of freedom of movement as documented in the constitution of Federal Republic of Nigeria. Kidnapping is perceived as an act of an angry man who wants to take any person of value hostage, and who could be rescued by loved ones. In most cases, victims are often released after payment of ransom (Nwaorah, 2009). Kidnapping is a serious criminal offence. It is an act of seizing, taking away and keeping a person in custody either by force or fraud. However, it includes snatching and seizing of a person in order to collect a ransom in return or settle some scores of disagreement among people.

Changes of societal values will lead to degeneration in moral behaviour as implied by Obasola (2015) in Olulowo (2017) where it was argued that, the concept of morality serves as the foundation upon which the construction of a truly righteous and classless society rests. Similarly, moral principles form a fundamental aspect of every culture as they outline broadly, codes of behaviour or conducts for the individual, on the one hand, and the society, on the other. 
Crimes: It is violation of societal rules of behaviour as interpreted and expressed by a criminal legal code created by people holding social and political power. Individuals who violate these rules are subject to sanctions by state authority, social stigma and loss of status. Thomas and Nta (2009) explained kidnapping as stealing of the highest order. It is a prearranged and orderly robbery which is not as fatal as armed-robbery, but more lucrative than the former. The profitability has encouraged those that engaged in it to carry on with the act although there is a law prohibiting it. In criminal law, kidnapping is defined as taking away of a person by force, threat or deceit with intent to cause him/her to be detained against his or her will (Asuquo, 2009).

Kidnapping is a crime of unlawful, forceful seizure and detention of a person or persons against his/her or their wish, in anticipation of payment of ransom or to settle some scores of disagreement (Linus, 2015). It is restriction to someone else liberty which is a violation to the provision of freedom of movement as enshrined in the constitution of Federal Republic of Nigeria (Okonkwo, 1980). Siegel (1986) sees kidnapping by nature is an acquisitive crime which is an offense against the value system of a society.

Any person who unlawfully imprison, and take him out of Nigeria, without his consent, or unlawfully imprison any person within Nigeria in such a manner as to prevent him from applying to a court for his release or from discovering to any other person the place where he is imprisoned, or in such a manner as to prevent any person entitled to have access to him from discovering the place where he is imprisoned. Is guilty of felony and is liable to imprisonment for ten years (Section 364 of Nigeria Criminal Code). Ugwu (2010) avowed that, there is a dehumanizing tendency involved in the crime of kidnapping as it often leads to the death of the victim. The view of Ugwu is essentially true because kidnapping crime is carried out in our country, the issue is usually beyond ransom taking because death 
is usually a resultant consequence, for those who cannot or whose people could not meet up with the often exorbitant amount called out for as ransom even after a disgracing bargain or negotiation.

Socio-Religious Ethics: The executive summary of Saint Augustine ethical theory was reflected in one of his prayers in which he asked God to give him what God commanded and God should command what God willed. He linked moral content to divine status of morality to the idea of God. God was related to moral standards. Augustine averred that the will of God whatever its content was good and was a source of blessing. Thus, the entire issues of morality were found in an appeal to God and a love for him. Aristotle is of the opinion that many people abstain from crimes because of their fear of penalties. They are never moved by a sense of honour, respect or dignity to avoid criminal actions. This he posits, is the reason why such people cannot experience true happiness (Dzurgba, 1989). Agents of societal ethics have been saddled with the responsibility of impacting societal ethical values. These are those who by virtue of their positions in the society have been given this noble task. As it is very obvious, that man unaided may not adhere or obey any societal ethics. It was also noted from experience that every man has propensity to be selfish indeed and unless self-centeredness is restricted by a means of social control, there would be conflicts of interest among members of the society. Therefore, to behave in such a way that will take into consideration the interest of others around us or who our behaviour could affect is taken into serious consideration is the focal teaching of religious ethics. Hence, there is an urgent need for the agents of religious ethics who will teach and inculcate ethics of religion. Thus, these agents could be both the visible and invisible agents (Olulowo, 2017 adapted from Ayantayo, 2009).

It is also noted that because societal ethics is "persons and interpersonal related', it confers some responsibilities of teaching and 
articulating it on some people. Certain agents are saddled with such obligation. However, they apply both religious and secular procedures to teach it and the message they pass across is for the benefit of the people in the society irrespective of their religious disposition. He argued that this is possible because religious people live in the society generally where there is the tendency to borrow secular methods of coaching ethics. This research will discuss agents and methods of teaching ethics as related to issue of Kidnapping as they manifest in school, tradition and Christianity. Ayantayo (2009) noted further that in Christianity, the Holy Spirit constitutes an agent of imbibing religious ethics. This $\mathrm{He}$, does by inspiring Christians, motivating them to do whatsoever is right. This assertion is attested to by the following Old and New Testament scriptures (Numbers 11:29, 24:2, 1 Samuel 16: 6, 21, 2 Samuel 23: 2; Hosea 9: 7); and teaches people (Luke 12: 12; John 114: 26). The Bible teaches that the Holy Spirit teaches, gives counsel, truthful, omnipresent and benevolent (Isaiah 40: 13 \& Deut. 4: 8-9 and 18; Neh. 9: 20, and John 5:6, Psa. 139: 710). The implication of this is that Holy Spirit dwells in people as exemplified in the following scriptural passages (Ezek 36: 27, John 14: 7; Rom. 8: 9; 1 Cor. 3: 16; 6: 16; 2 Timothy 1: 14; 1 John 2: 27).

Other human agents or channels through who the Holy Spirit works for articulating Christian ethical values are the Clergy, Pastors or Reverend Ministers male and female alike, Prophets and Prophetess, Evangelists, Deacons and Deaconesses, Elders, Sunday School Teachers, Juvenile Teachers, Leaders of Christian societies, unions and Church Associations (Adeogun, 1986). Other responsible agents for inculcating social ethics are Christian education centres such as seminary, theological colleges, mission schools, monasteries and convents, hospitals, orphanages, rehabilitation centres, leprosaria etc. Each of the above complements the other in their mode of operations. The Bible serves as their guide. The Church has the right to punish anyone who violates the ethical sequencers and sometimes 
they could even expel or give other punitive measures (Ayantayo, 2009). Olulowo (2018) noted that societal agents of ethical code and conduct are the combination of both secular and religious leaders. They comprises of the Kings and paramount rulers; Leaders of clans and villages; the head of families, teachers of all primaries, secondary and tertiary institutions; the law enforcement agents, members of all Para military and the military institutions and Political leaders and all political office holders.

\section{The Causes of Kidnapping}

Ohakhire (2010) clarified that kidnapping is associated with quest for ransom, revenge and ritual. That is the dictum of kidnapping ' 3 rs' of kidnapping. Other researchers have also campaigned for the following reasons to be responsible for Kidnapping:

1. Challenge of Poverty: Poverty is a global phenomenon which is a recurring problem in Nigeria. It is evident from personal observation, scholarly works, newspaper, radio and television that despite its abundant resources and oil wealth, Nigeria is ravaged by poverty. The situation has worsened since the late 1990's to the extent that the country is considered one of the twenty poorest countries in the world; over seventy percent of the population is classified as poor with about thirty five percent living in abject poverty (Rural Poverty Portal, 2008). Kinoti (1994) in Olulowo (2017) posited that poverty is directly related to crime. He contends that if people do not have enough to eat, they steal to survive. When people become desperate for food and other necessities they will steal and even kill to get what they need. The 2004 Human Development Indicators put Nigeria as number 151 out of 177 countries. Poverty in Nigeria is generally believed to be prime cause of kidnapping in the country. 
2. Challenge of Unemployment: Lack of employment opportunities for the youths in different parts of Nigeria is one major cause of prevalence of kidnapping. Inyang (2009) associated kidnapping to the endemic rate of youth joblessness. He corroborated this fact by citing the widely acknowledged adage, which says that "an idle man is the devil's workshop" to present the situation of unemployment in Nigeria. Linus (2015) noted that there are uncountable able-bodied men and women in Nigeria roaming the streets in search of non existing job. Out of frustration together with mounting responsibilities to tackle many idle young persons have ventured into criminal activities of which kidnapping are not an exemption. A graduate who is unable to secure a job is psychologically bereft of other means of survival. Such. The existence of vast reservoir of unemployed youths and underground republic in the country. It is called the republic of hoodlums, a reservoir of almost limitless supply of hungry, angry, willing and able fighters for murky causes. It is from this army that the various ethnic militias and kidnappers are drawing their cadre (Amuta, 2001).

3. Proliferation of Arms and Military Uniforms: Inyang (2009) in Ilechukwu Leonard Chidi, Uchem and Asogwa Uche (2015) believed that the purchase of large number of arms as a result of political patronage of miscreant who were dumped after elections may indirectly encourage and enhance kidnapping. He equated today's kidnapping situation to the bane of arm robbery in the early eighties where many young-able bodied men who fought during the Nigerian civil war were discharged and sent home with nothing. Meanwhile since the schools they left behind were destroyed and there were no jobs to engage them and keep them busy. Many of them consequently took to armed robbery, since as ex-soldiers they were armed with weapons, having acquired the skill and guns during the war. The story is almost the same today as politicians employ most idle youths as 
political thugs and later dumped them after elections. Therefore, the youths (thugs) who have been abandoned by their master after winning elections are now busy kidnapping innocent person and relative of those persons they surged to be wealthy (Inyang and Ubong, 2013).

4. Policy of Cashless Economy: Some are of the opinion that, the prevalence of kidnapping is no unconnected with the recent cashless economy that had reduced the possibility of pilfering huge amount of cash. They added that the armed robbers then transform into kidnapping. Those robbers see kidnapping as being more lucrative than stealing (Linus, 2015).

\section{Moral Decadence and Quest to Get Rich Quick Syndrome}

The challenge of moral decadence and the quest to get rich syndrome are some of causative factors of kidnapping according to Inyang and Ubong (2013). Inyang (2009) again established these in his proposition that in Nigeria, nobody asks questions on how people make their wealth. He contended that a poor person today, can show up with an expensive car tomorrow and nobody dare to question the sudden wealth. He further asserted that people who have donated money to develop their communities are rewarded with chieftaincy titles thereby creating a wrong impression in the minds of Nigerian youth who thereafter take to kidnapping. Inyang and Ubong (2013) identified greed as one of causes of kidnapping in Nigeria. They averred that, greed has caused many persons to take part in heinous criminal acts. Kidnapping is perhaps one crime that promotes greed and despair on the human person. For many, it is greed that pushes perpetrators to brutalize and torture a stranger and put his family through a cruel ordeal for weeks, months sometimes years. 
6. Corruption and Poor Governance: The economic failure is attributed to wearing down of the state's institutional and administrative capacities, corruption pandemic, inconsistency in economic policy, external shocks, poor state of the rule of law and military dictatorship, rising ethnic nationality conflicts and the state's inability to implement its policies and decisions due to corruption and refraction of such policies through prism of ethnic and sectional interest provoked some other sections to criminality especially that of kidnapping (Arewa, 2013). This is called the breakdown of institutional infrastructures (Fukuyama, 2004). The foundations of institutional framework in Nigeria are very insecure and have motivated a weakening of state governance and democratic accountability, thus, paralyzing the existing formal and legitimate rules nested in the hierarchy of social order (Achumba, et al, 2013). The state of insecurity in Nigeria is a function of government failure. This manifests in the incapacity of government to deliver public goods to its citizens (Igbuzor, 2011). This lack of basic necessities by the Nigerian people has created a growing army of frustrated people who resort to violence at the slightest provocation or opportunity. Even though, Nigeria is full of resources to meet the needs of her people, the well-established culture of corruption in public service has brought about the drought of basic necessities.

\section{Problem Inadequate Equipment of Law enforcement Agencies:}

Thon-Otuya (2010) posits that most of the kidnaps carried out by the militant that their victims are always ferried to the creek for custody. She further asserts that the Nigerian navy does not have enough functional equipment to monitor and secure the porous water way. The Navy, according to her, has only about ten (10) combat ships with about twelve (12) defender boats; none of this ship is below thirty years. She is inadequately equipped to police her sea lanes, and this makes her inadequately equipped to monitor sea pirates and 
kidnap activities. The police and the customs are also ill equipped to match the sophisticated weapons been used by these hoodlum.. Apart from inadequate equipment, the members of the law enforcement agents are corrupt and lack will power to fight the criminals to conclusive end.

\section{Loss of the Patriarchal Authority by Nigerian State}

Nigeria has lost the patriarchal moral authority which is necessary in the socialization process, the same way, a father who ought to constitute the central and dominant figure in a family unit loses authority as a result of his failure to discharge his obligations as the central and dominant figure to Meetfor the needs of members of his household (Arewa, 2013). Patriarchal authority emanates from consistency in the discharge of those obligations. Where the obligations are habitually discharged in the breach, the patriarch loses its grip and progressively becomes unable to rein in the behaviour of the citizenry. Extreme poverty in the country as a result of Job lost has made some parents to relinquished some of their duties as bread winners of the house Hence, poverty has turned many young adults into bread-winners in their different families. In order to have their needs and that of their family members met, some girls to engage in premarital sex and boys do engage in other heinous crimes such as kidnapping, drug peddling, arm robbery and ritual killings to get money but little or no attention is paid to the source of the money; even when parents become aware of the source, their sense of judgment is beclouded by the shame of their inability to play their primary role in providing for their homes. They simply rationalize that, after all, the needs are met. The popular slogan among young adults today is 'use what you have to get what you want' (Olulowo, 2017). 


\section{The Use of Hard Drug}

The increase of kidnapping is connected to high use and trafficking of hard drugs (Okoli, 2009). The use of hard drugs no doubt leads to violent crimes such as kidnapping and armed robbery within the country. Several drug sale joints are emerging everyday where criminal activities are planned, perfected and executed. Some streets in the state have been turned into no-go areas for law abiding residents as unscrupulous miscreants have turned them into ghettos and hideouts for their hard drugs operation. After taking the drugs, the takers became high, fearless, bold and inhuman and they can perpetrate kidnapping under this state of mind without qualms of conscience.

\section{Inequality and Absence of Fairness and Justice}

The perception of marginalization by many Nigerians is informed by the ostentation showed by thePolitical class and elite vis-à-vis the grinding poverty to which citizens was subjected to. Even security has been bourgeoisified by the elite. As Egwu (2000) contends, the security of the Nigerian nation-state has been reduced to that of the ruler and his immediate supporters, thus, the security calculus of the Nigerianstate has failed because it does not include vital aspects of social and national development supported by the provision of basic social, economic or even military conditions necessary for effective national security. This state of inequality, unfairness and injustice has toughened the people, forcing them to take their destiny into their hands.

\section{The Consequences of Kidnapping}

Economic Effect of Kidnapping: Inyang and Ubong (2013) in Ilechukwu (2015) averred that the economic effects of kidnapping include direct and indirect costs. Direct Cost of Kidnapping involves the economic value that individuals and government may be lost to 
kidnappers, much money has been paid as ransom. Former Inspector of Police, Sir Mike Okiro, reported that N15 billion have been paid as ransom to the kidnappers between 2006 and 2009 (Kyrian, 2009). Inyang and Ubong (2013) posited out that in many cases, it is often the bread winners of families that are usually targeted, the implication is always felt particularly within the family, whereby members of such families will have to feed themselves and adjust to their normal daily activities, until they secure the release of the victim. If the victim is a businessman or woman the business will suffer, if he is a civil servant or an artisan, his place of work will be affected adversely. In both cases there is going to be some setback. Indirect Cost of Kidnapping includes expenditure on preventive measures, such as the employment of private security personnel. At government level, the economic effects include the expenditure on security and security agencies (Inyang and Ubong, 2013).

\section{Political Effects of Kidnapping}

Kidnapping can create political effects like:

1. Elective and Political Violence: There can be increase in the use of political thugs of strong politicians to threaten their political opponents, thereby derailing the democratic process (Thom-Otuya, 2010).

2. According to Thom-Outya (201) the alarming rate of kidnapping activities in the country could overturn democracyand pave way for military invasion into politics and send the politicians parking. If political gladiators will usekidnapping, as established crime in Nigeria to intimidate their opponent, then, they will be prompting militarystorming into Nigeria politics to remedy the insecurity of lives, properties and business with military dispatch.This according 
to (Otuya, 2010) will lead to the utmost backwardness of Nigeria society.

3. Kidnapping activities shoot up the abundance of arms. The business requires good firing power i.e firearms inorder to kidnap the targeted victims, to scare people out of the sight and to resist the law enforcement agents.Politicians equip the thugs with arms to use in threatening their opponents.

4. The inability of the security agencies to stop kidnapping occurrences in the country exposes the weakness of thesecurity agencies in the country.

\section{Social Effects of Kidnapping}

1. Kidnapping affects the social life and social relation of many people who are held hostages in their homes from dust to dawn, for fear of being kidnapped (Inyang and Ubong 2013). As a result of kidnapping, night travel has become a high risk. Furthermore, many people have been forced out of their newly completed houses by kidnappers. People are compelled to present an unfinished look of poverty by not painting the external walls of their houses. Many people are afraid to buy or use new motor vehicles for the fear of kidnappers. Soyombo (2009), attests that rich people have resorted to riding in taxi cab and commercial motorcycle popularly called Okada to markets, schools, offices and social outings as a means to check hostage takers.

2. Theincident of kidnapping in the era of democracy in Nigeria dents the image of the nation in the global scene (Ilechuckwu et al. 2015).Thom-Otuya (2010) observed that in the game of international relations, the image and prestige of a countryis very important to her interest. If Nigeria that ought to attract foreign 
investors has a very poor and dentedimage, she will probably find it difficult making friends and attracting foreign investors. The truth of thematter is exposed by Odey (2001) when he noted that everywhere in the world; Nigerians are generallyfeared like dogs, dreaded like criminals, cautiously approached like snakes and avoided as a leper.

\section{Psychological/Emotional Effects}

Kidnapping creates physical and psychological fear of insecurity among the Nigerians. This makes contractors to abandon their project due to fear of being kidnapped. This trend retards growth and development. For instance, oil workers abandoned their job for their safety, at the detriment to oil production which is the main source of our economy. Nigeria earns over $90 \%$ of foreign exchange from oil and gas production as result of kidnapping. It translates to great threat to the National security and challenges to the government and law enforcement agency. Fear of insecurity could lead to migration of foreign investors to other countries. Consequently this creates capital flight from the state thereby affecting the economy of the nation. Companies can be closed making some people jobless. This could create threat to security of the nation (Ilechuckwu et al. 2015).

\section{Moral Effects of Kidnapping}

1. Some victims of the kidnappers could be sexually abused in the process of their captors await the demanded payment (Ilechuckwu et al. 2015)

2. Some victims of the kidnappers have lost their lives in the hands of their abductors. ForInstance: Dr. Gabriel Olowoyo, the Attah of Aiyede Orisagbeni died in motor accident when he was being transported by the kidnappers; Henrian Omovegie was kidnapped and killed in Delta state; Mrs. Owoidighe Ekpoattai and two policemen died in the hand of their abductors, among many others. 
Life is sacred, but kidnappers have made human life to lose its value. Their immoral acts have reduced man into semblance of animals. They have made man to lose his freedom and dignity (Ilechuckwu et al. 2015)

\section{Methodology}

The research design was both descriptive survey method of enquiry and the historical research method. It utilized both primary and secondary sources of data collections. These data were collected, organized and critically analyzed. Christians from the Pentecostal, Mainline, Evangelicals and African Independent Churches in the three Senatorial Districts of Ogun State, Nigeria constituted the population for this study. Structured questionnaire is designated to gather data from three senatorial districts of Ogun states and they are: Ogun East, Ogun Central and Ogun West. Thus, for the three senatorial districts a total of 12 churches were purposively selected to represent the state for the purpose of the administration of questionnaires. Thus we have 200 copies of questionnaires to be administered on selected Pentecostal, Evangelical, Mainline and African Independent Churches in each of the 3 senatorial districts of the State. A total of 600 copies of the questionnaire were administered in the three senatorial districts of Ogun State. The questionnaire has 16 items under various headings; the instrument has sections $1 \& 2$. Section 1 seeks the respondents' opinion about the causes of kidnapping prevalence in Ogun State. Section 2 gathers data on consequences of kidnapping in Ogun State and on the Church particularly. The instrument was prepared with scale question method which requires the respondents to choose in terms of categories of certain option and phenomena of interests. This necessitates the use of strongly agrees (SA), Agree (A), Disagree (D) and Strongly Disagree (SD). A total of 600 questionnaires were administered among Christians from the Pentecostal, mainline, evangelicals and African 
independent churches and tertiary institutions in the three senatorial districts of Ogun State South-West Nigeria. Four hundred and seventy two (472) were retrieved and found usable, which represent the return rate of $78.7 \%$ (seventy eight point six percent) these were deemed good enough to be subjected to statistical analysis. Data collected in this study was quantitatively interpreted and analyzed using descriptive statistics such as Frequency count, percentages (\%), Mean (X) and standard deviation (SD). The analysis was done based on each research questions raised. The statistical package for the social sciences (SPSS) was used to analyze the data.

\section{Tables of Results}

\section{Section 1- Causes of Kidnappings in Ogun State}

Research Question One: - What Are the Causes of Kidnapping in Ogun State?

\section{Table 1: The Causes of Kidnapping in Ogun State}

\begin{tabular}{|c|c|c|c|c|c|}
\hline $\mathbf{S} / \mathbf{N}$ & & SA & $\mathbf{A}$ & D & SD \\
\hline 1 & $\begin{array}{l}\text { Kidnapping is associated with } \\
\text { quest for ransom, revenge and } \\
\text { ritual. }\end{array}$ & \begin{tabular}{|l|}
344 \\
$(72.88)$
\end{tabular} & 63 (26.69) & $2(0.42)$ & \begin{tabular}{|l}
--- \\
\end{tabular} \\
\hline 2 & $\begin{array}{l}\text { Poverty and social injustice } \\
\text { leads to frustration which } \\
\text { incline citizens to criminality. }\end{array}$ & \begin{tabular}{|l|}
330 \\
$(69.92)$
\end{tabular} & $132(27.97)$ & $10(2.12)$ & $\mid--$ \\
\hline 3 & $\begin{array}{l}\text { Lack of employment } \\
\text { opportunities for the youths is } \\
\text { one major cause of prevalence } \\
\text { of kidnapping }\end{array}$ & $322(68.22)$ & $142(30.08)$ & $4(0.85)$ & $4(0.85)$ \\
\hline 4 & $\begin{array}{l}\text { Proliferation of Arms with } \\
\text { military uniforms and } \\
\text { politicians patronizes } \\
\text { miscreants enhances } \\
\text { kidnapping }\end{array}$ & $294(62.29)$ & $132(22.97)$ & $24(5.08)$ & $22(4.66)$ \\
\hline 5 & $\begin{array}{l}\text { Moral Decadence and Quest } \\
\text { to Get Rich Quick Syndrome } \\
\text { among youths predisposes }\end{array}$ & $324(68.64)$ & $142(30.08)$ & $2(0.42)$ & $4(0.85)$ \\
\hline
\end{tabular}


Olulowo, Babawale \& Anani: An Examination of the Causes of Kidnapping and Its Attendant Challenges in Ogun State, Nigeria

\begin{tabular}{|c|l|l|l|l|l|}
\hline & them to kidnapping & & & & \\
\hline 6 & $\begin{array}{l}\text { Government lacks of equity } \\
\text { and fairness in the business of } \\
\text { governance causes kidnapping }\end{array}$ & $314(65.53)$ & $150(31.78)$ & $4(0.85)$ & $4(0.85)$ \\
\hline 7 & $\begin{array}{l}\text { Inadequate equipping of law } \\
\text { enforcement Agencies and } \\
\text { corruptions makes them lack } \\
\text { the will power to combat } \\
\text { kidnapping }\end{array}$ & $320(68.09)$ & $146(31.06)$ & $2(0.42)$ & $4(0.85)$ \\
\hline 8 & $\begin{array}{l}\text { The increase of kidnapping is } \\
\text { connected with high use and } \\
\text { trafficking of hard drugs }\end{array}$ & $164(34.75)$ & $132(22.97)$ & $4(0.85)$ & $4(0.85)$ \\
\hline
\end{tabular}

Table 7 showed the Causes of Kidnapping in Ogun State as perceived by the respondents. Majority of the respondents are in agreement with the issues raised in the instrument as to the Causes of Kidnapping in Ogun State. Those that admitted that each of the eight (8) items on the Causes of Kidnapping in Ogun State were above $90 \%$ in each case. Conversely, in the opinion of the respondents; they are in agreement with the following statements:

1. Kidnapping is associated with quest for ransom, revenge and ritual.

2. Poverty and social injustice leads to: lacks and frustration which incline citizens to criminality as means of survival.

3. Lack of employment opportunities for the youths in Ogun State is one major cause of prevalence of kidnapping

4. Proliferation of Arms with military uniforms and politicians patronises miscreants enhances kidnapping

5. Moral Decadence and Quest to Get Rich Quick Syndrome among youths predisposes them to kidnapping

6. Government lacks of equity and fairness in the business of governance causes kidnapping

7. Inadequate equipping of law enforcement Agencies and corruptions makes them lack the will power to combat kidnapping 
8. The increase of kidnapping is connected with high use and trafficking of hard drugs

Section 2: In this section, the data collected were analysed to provide answers to the research questions raised in chapter one.

Research Question Two: What Are the Roles of the Church in

Curbing Kidnapping in Ogun State?

\section{Table 2: The Roles of the Education, Government and Church in Curbing Kidnapping in Ogun State}

\begin{tabular}{|c|l|l|l|l|l|}
\hline S/N & \multicolumn{1}{|c|}{ SA } & A & D & SD \\
\hline 1 & $\begin{array}{l}\text { The Church as agents of } \\
\text { societal ethics has been } \\
\text { saddled with the } \\
\text { responsibility of impacting } \\
\text { societal ethical values. }\end{array}$ & $300(63.56)$ & $172(36.44)$ & ----- & ----- \\
\hline 2 & $\begin{array}{l}\text { The Church should teach that } \\
\text { people must be moved by a } \\
\text { sense of honour, respect or } \\
\text { dignity to avoid criminal } \\
\text { actions. }\end{array}$ & $312(66.10)$ & $156(33.05)$ & $4(0.85)$ & ----- \\
\hline 3 & $\begin{array}{l}\text { The focal teaching of } \\
\text { religious ethics should be } \\
\text { that people must behave in } \\
\text { such a way that will take into } \\
\text { consideration the interest of } \\
\text { others around us or who our } \\
\text { behaviour could affect. }\end{array}$ & $306(64.83)$ & $162(34.32)$ & $4(0.85)$ & ------ \\
\hline 4 & $\begin{array}{l}\text { The church ethical agents } \\
\text { should teach Bible ethics in } \\
\text { the power of the Holy Spirit } \\
\text { for it to make the needed } \\
\text { impact and bring about } \\
\text { behavioural and attitudinal } \\
\text { change }\end{array}$ & $298(63.14)$ & $168(35.59)$ & $4(0.85)$ & ------ \\
\hline
\end{tabular}




\begin{tabular}{|c|l|l|l|l|l|}
\hline 5 & $\begin{array}{l}\text { The Church ethical agents } \\
\text { must encourage baptism of } \\
\text { the Holy spirit for } \\
\text { parishioners that have been } \\
\text { saved; because he inspires } \\
\text { Christians, motivating them } \\
\text { to do whatsoever is right. }\end{array}$ & $352(74.58)$ & $116(24.58)$ & $4(0.85)$ & ------ \\
\hline 6 & $\begin{array}{l}\text { Church should encourage } \\
\text { Christian education centers } \\
\text { such as seminary, mission } \\
\text { schools, monasteries and } \\
\text { convents, hospitals, } \\
\text { rehabilitation centers, } \\
\text { leprosaria who themselves } \\
\text { are responsible agents for } \\
\text { inculcating social ethics. }\end{array}$ & $360(76.27)$ & $108(22.88)$ & $4(0.85)$ & ------ \\
\hline 7 & $\begin{array}{l}\text { Societal agents of ethical } \\
\text { code and conduct are the } \\
\text { combination of both secular } \\
\text { and religious leaders such as } \\
\text { Kings and paramount rulers; } \\
\text { Leaders of clans and villages; } \\
\text { the head of families e. t. c. }\end{array}$ & $332(70.34)$ & $124(26.27)$ & $4(0.85)$ & ------- \\
\hline 8 & $\begin{array}{l}\text { The church should therefore } \\
\text { use their every opportunity at } \\
\text { their disposal to influence } \\
\text { political leaders and other } \\
\text { secular leaders in the church } \\
\text { to make policies that will } \\
\text { reduce the high level of } \\
\text { poverty and unemployment } \\
\text { in the country. }\end{array}$ & & & & \\
\hline
\end{tabular}

Table 9 above showed the Roles of the Church in Curbing Kidnapping in Ogun State as perceived by the respondents of the study. Majority of the respondents are in agreement with the issues raised in the instrument as to the strategies that if employed will curb kidnappings. Those that admitted that each of the eight (8) items is good strategies 
that can be used by the church to curb kidnappings were above $65 \%$ and above in each case. Conversely, in the opinion of the respondents; they are in agreement with the following statements:

1. The Church as agents of societal ethics has been saddled with the responsibility of impacting societal ethical values.

2. The Church should teach that people must be moved by a sense of honour, respect or dignity to avoid criminal actions.

3. The focal teaching of religious ethics should be that people must behave in such a way that will take into consideration the interest of others around us or who our behaviour could affect.

4. The church ethical agents should teach Bible ethics in the power of the Holy Spirit for it to make the needed impact and bring about behavioural and attitudinal change

5. The Church ethical agents must encourage baptism of the Holy Spirit for parishioners that have been saved; because he inspires Christians, motivating them to do whatsoever is right.

6. Church should encourage Christian education centers such as seminary, mission schools, monasteries and convents, hospitals, rehabilitation centers, leprosaria who themselves are responsible agents for inculcating social ethics.

7. Societal agents of ethical code and conduct are the combination of both secular and religious leaders such as Kings and paramount rulers; Leaders of clans and villages; the head of families' e. t. c.

8. The church should therefore use their every opportunity at their disposal to influence political leaders and other secular leaders in the church to make policies that will reduce the high level of poverty and unemployment in the country.

\section{Discussion of Findings}

Section A: Probes the causes of Kidnapping in Ogun State

Under this section, we shall be discussing each of these items as follows: 
Item No. 1 affirmed that Kidnapping is associated with quest for ransom, revenge and ritual. Out of a total of 472 respondents, a majority of 470 respondents representing $99.58 \%$ agreed that Kidnapping is associated with quest for ransom, revenge and ritual. While the minority two respondents representing $0.42 \%$ disagreed with this assertion. This decision of majority of the respondents agrees totally with Ohakhire (2010) and Olulowo (2010) who both clarified that kidnapping is associated with quest for ransom, revenge and ritual or any form of crime. They averred that Ritual killings, which are so common in our society, can also be traced back to the problem of suffering.

Item No. 2 affirmed that Poverty and social injustice leads to frustration which inclines citizens to criminality as means of survival. Out of a total of 472 respondents, a majority of 462 respondents representing $97.88 \%$ agreed that Poverty and social injustice leads to frustration which inclines citizens to criminality as means of survival. While the minority ten respondents representing $0.42 \%$ disagreed with this assertion. The decision of the majority of the respondents was in agreement with Olulowo (2010) also observed that increase in the rate of cultism on our campuses can be traced back to a lot of children who are trying to cover up for their damaged self estimation. Poverty in the family has brought out the worst of every member of the family.

Item No. 3 affirmed that lack of employment opportunities for the youths in Ogun State is one major cause of prevalence of kidnapping. Out of a total of 472 respondents, a majority of 464 respondents representing $98.30 \%$ agreed that lack of employment opportunities for the youths is one major cause of prevalence of kidnapping. While the minority of eight of the respondents representing $1.7 \%$ disagreed with this assertion. The decision of the majority of the respondents is a re- 
enforcement of the opinions of the following researchers whose work were cited in the review of literatures, Amuta (2001), Inyang (2009) and Linus (2015) that all associated kidnapping to the endemic rate of youth joblessness and citing the widely acknowledged adage, which says that "an idle man is the devil's workshop" and noted that there are uncountable able-bodied men and women in Nigeria roaming the streets in search of non existing job which out of frustration together with mounting responsibilities to tackle many idle young persons have ventured into criminal activities of which kidnapping are not an exemption.

Item No. 4 affirmed that Proliferation of Arms with military uniforms and politicians patronises miscreants enhances kidnapping. Out of a total of 472 respondents, a majority of 426 respondents representing $90.25 \%$ agreed that Proliferation of Arms with military uniforms and politicians patronises miscreants enhances kidnapping. While the minority of 46 of the respondents representing $9.75 \%$ disagreed with this assertion. The claimed of the majority is supported by Oluyinmi (2004) and Ukandu (2011), who both have affirmed that societies that this is especially true of Nigeria where after the Nigeria-Biafra encounter, arms proliferation of various types were made available in towns and even villages across the nation. Patterns of violent crimes here imply the ways, methods of operation and the structure that is exhibited and utilized during violent crimes in Nigeria.

Item No. 5 affirmed that Moral Decadence and Quest to Get Rich Quick Syndrome among youths predisposes them to kidnapping. Out of a total of 472 respondents, a majority of 466 respondents representing 98.93\% agreed that Moral Decadence and Quest to Get Rich Quick Syndrome among youths predisposes them to kidnapping. While the minority of six of the respondents representing $1.27 \%$ disagreed with this assertion. The claimed of the majority is supported 
by Ubong (2013) and Inyang (2009) who both established these in his proposition that in Nigeria, nobody asks questions on how people make their wealth. He contended that a poor person today, can show up with an expensive car tomorrow and nobody dare to question the sudden wealth. He further asserted that people who have donated money to develop their communities are rewarded with chieftaincy titles thereby creating a wrong impression in the minds of Nigerian youth who thereafter take to kidnapping.

Item No. 6 affirmed that Government lacks of equity and fairness in the business of governance causes kidnapping. Out of a total of 472 respondents, a majority of 464 respondents representing $98.31 \%$ ) agreed that Government lacks of equity and fairness in the business of governance causes kidnapping. While the minority of eight of the respondents representing $1.7 \%$ disagreed with this assertion. The claimed of the majority is supported by Arewa (2013) briefly pointed out that as a result upon the collapse of the parliamentary system in Nigeria through degeneration and revolutionary ouster, the state, its laws and institutions became dedicated instruments of despots and political forces and allowed to slip deeper and deeper in the mire of corruption and malfeasance far beyond the transformation. This view is collaborated by Igbuzor (2011) who sees the state of insecurity in Nigeria as a function of government failure. This manifests in the incapacity of government to deliver public goods to its citizens. This lack of basic necessities by the Nigerian people has created a growing army of frustrated people who resort to violence at the slightest provocation or opportunity.

Item No. 7 affirmed that inadequate equipping of law enforcement Agencies and corruptions makes them lack the will power to combat kidnapping. Out of a total of 472 respondents, a majority of 456 respondents representing $98.93 \%$ agreed that inadequate equipping of 
law enforcement Agencies and corruptions makes them lack the will power to combat kidnapping. While the minority of eight of the respondents representing $1.7 \%$ disagreed with this assertion. The claimed of the majority is supported by Thon-Otuya (2010) who posited that most of the kidnaps carried out by the militant that their victims are always ferried to the creek for custody. She further asserts that the Nigerian navy does not have enough functional equipment to monitor and secure the porous water way. The police and the customs are also ill equipped to match the sophisticated weapons been used by these hoodlum. Apart from inadequate equipment, the members of the law enforcement agents are corrupt and lack will power to fight the criminals to conclusive end.

Item No. 8 affirmed that the increase of kidnapping is connected with high use and trafficking of hard drugs. Out of a total of four 472 respondents, a majority of 460 respondents representing 97.46\%) agreed that the increase of kidnapping is connected with high use and trafficking of hard drugs. While the minority of twelve of the respondents representing $2.54 \%$ disagreed with this assertion. The claimed of the majority is supported by Okoli (2009) who averred that the increase of kidnapping is connected to high use and trafficking of hard drugs. The use of hard drugs no doubt leads to violent crimes such as kidnapping and armed robbery within the country. Several drug sale joints are emerging everyday where criminal activities are planned, perfected and executed.

\section{Research Question 2: - What Are the Roles of the Church in Curbing Kidnapping in Ogun State? Those that admitted that each of the eight (8) items that are strategies that can be used by the church to curb kidnappings were above $65 \%$ and above in each case. Conversely, in the opinion of the respondents; they are in agreement with the following statements:}


Item No. 1 affirmed that the Church as agents of societal ethics has been saddled with the responsibility of impacting societal ethical values. Out of a total of 472 respondents, a total of the majority of 468 respondents representing tone hundred $(100 \%)$ percent agreed that the Church as agents of societal ethics has been saddled with the responsibility of impacting societal ethical values. The decision of the total respondents validates Religion and Education Policy (2005) that Religious Education is therefore an educational program for teaching and learning about religion in its broadest sense, about religions, and about religious diversity in the world. It pursues a balanced approach to teaching and learning about religion. It provides opportunities for both a deeper sense of self-realization and broader civil acceptance of others. It can facilitate the development of both empathetic appreciation and critical analysis.

Item No. 2 affirmed that the Church should teach that people must be moved by a sense of honour, respect or dignity to avoid criminal actions. Out of a total of 472 respondents, a majority of 468 respondents representing $99.15 \%$ agreed that the Church should teach that people must be moved by a sense of honour, respect or dignity to avoid criminal actions. While the minority of four of the respondents representing $0.85 \%$ disagreed with this assertion. The decision of the majority was affirmed by Aristotle who opined that many people abstain from crimes because of their fear of penalties. They are never moved by a sense of honour, respect or dignity to avoid criminal actions.

Item No. 3 affirmed that the focal teaching of religious ethics should be that people must behave in such a way that will take into consideration the interest of others around us or who our behaviour could affect. Out of a total of 472 respondents, a majority of 468 respondents representing $99.15 \%$ agreed that the focal teaching of 
religious ethics should be that people must behave in such a way that will take into consideration the interest of others around us or who our behaviour could affect. While the minority of four of the respondents representing $0.85 \%$ disagreed with this assertion. The vast majority of the respondents were validated by Olulowo (2018) who defined Church or Biblical education as those activities designed to induct each newly converted into the attitudes, beliefs and practices of the church therefore by perpetuating the church and at the same time providing for the individual with the opportunity to be connected with what is the will of God and the expectation of God for his life. It is also defined as the process by which any church coaches and trains its members, especially the young in its beliefs and practices.

Item No. 4 affirmed that the church ethical agents should teach Bible ethics in the power of the Holy Spirit for it to make the needed impact and bring about behavioural and attitudinal change Out of a total of 472 respondents, a majority of 466 respondents representing $98.75 \%$ agreed that the church ethical agents should teach Bible ethics in the power of the Holy Spirit for it to make the needed impact and bring about behavioural and attitudinal change. While the minority of seven of the respondents representing $1.27 \%$ disagreed with this assertion. The decision of the majority validates Ayantayo (2009) noted further that in Christianity, the Holy Spirit constitutes an agent of imbibing religious ethics. This $\mathrm{He}$, does by inspiring Christians, motivating them to do whatsoever is right. Ayantayo (2009) also validates the decision of majority of respondents to Item No. 5 whichaffirmed that the Church ethical agents must encourage baptism of the Holy Spirit for parishioners that have been saved; because he inspires Christians, motivating them to do whatsoever is right. Out of a total of 472 respondents, a majority of four hundred and sixty eight (468) respondents representing $99.15 \%$ agreed that the Church ethical agents must are encourage baptism of the Holy Spirit for parishioners 
that have been saved; because he inspires Christians, motivating them to do whatsoever is right. While the minority of four of the respondents representing $0.85 \%$ disagreed with this assertion.

Item No. 6 affirmed that Church should encourage Christian education centres such as seminary, mission schools, monasteries and convents, hospitals, rehabilitation centres, leprosaria who themselves are responsible agents for inculcating social ethics. Out of a total of 472 respondents, a majority of 468 respondents representing $99.15 \%$ agreed that Church should encourage Christian education centres such as seminary, mission schools, monasteries and convents, hospitals, rehabilitation centres, leprosaria who themselves are responsible agents for inculcating social ethics. While the minority of four of the respondents representing $0.85 \%$ disagreed with this assertion. Dealing with issues of violent crimes such as kidnapping the church need to fully equip and engaged all her education centres as mentioned above who are also themselves agents for inculcating social ethics.

Item No. 7 affirmed that Societal agents of ethical code and conduct are the combination of both secular and religious leaders such as Kings and paramount rulers; Leaders of clans and villages; the head of families' e. t. c. Out of a total of 472 respondents, a majority of 456 respondents representing $96.61 \%$ agreed that Societal agents of ethical code and conduct are the combination of both secular and religious leaders such as Kings and paramount rulers; Leaders of clans and villages; the head of families' e. t. c. While the minority of four of the respondents representing $0.85 \%$ disagreed with this assertion. Religion and Education Policy (2005) validates advocated for a synergy of styles and methods of both the secular and the sacred in combating crimes especially kidnappings.. It creates a context in which people can increase their understanding of themselves and 
others develop powers of critical reflection in thinking through problems of religious or moral concern.

Item No. 8 affirmed that the church should therefore use their every opportunity at their disposal to influence political leaders and other secular leaders in the church to make policies that will reduce the high level of poverty and unemployment in the country. Out of a total of 472 respondents, a majority of 310 respondents representing $65.68 \%$ agreed that the church should therefore use their every opportunity at their disposal to influence political leaders and other secular leaders in the church to make policies that will reduce the high level of poverty and unemployment in the country. While the minority of 162 of the respondents representing $34.32 \%$ disagreed with this assertion. These writers totally agree with the majority of the respondents because majority of potential perpetrator of any crime at least attend church or any other religious worship house or centre. And if the worship leaders do not play game or compromised their assignment and faithfully carry out every assignment in the power of the Holy Spirit. Most of the tendencies to commit crimes can be destroy before they bloom and blossom.

\section{Conclusion and Recommendations}

The paper concludes and affirmed the existence of kidnappers has become a thorn in the flesh of many citizens and foreigners domicile in Ogun state South West Nigeria. Kidnapping is growing at an extraordinary rate across the State. People's movements to their working places have been hampered by the fear of kidnappers. The paper examine causes of kidnapping, highlights its consequences and scrutinize the roles of schools, religious organisation and government in tackling kidnapping as a social problem. The nature of Kidnappings in the state is in no way having any political undertone but is mostly associated with quest for ransom, revenge and rituals 
and it poses the following threats to: the life of the entire citizens of the State, the growth and development of the economy of the State, it impacted more negatively on the growth and development of Churches in the State. The prevalence of kidnappings create an ambience of fear, distrust and worries among members of the church, affects their personal spiritual growth and cause a dwindling in their morale in church attendance and commitments especially to programs that would aids church growth and developments. It reduces the fruitfulness of the church to the barest minimum because at such time the church cannot be at her best in terms of evangelism, outreaches, giving, discipleship and mentoring. This paper is advocating Christian Religious education by exposing young adults to ethics and ethical values of the Bible. The study takes advantage of the power of the word of God not only to fill people with knowledge but also to impact behavioural change in people. Therefore, the study will offer recommendations to all stakeholders on the issue of crime managements and control such as parents, kings and paramount rulers, community leaders, Policemen and women, the military and paramilitary people, politicians, civil servants and public office holders, the school administrators, teachers, counselors, church ministers and the laymen alike. They will be helped in their advocacy against kidnapping. It, thus, put the collective responsibility on these stakeholders to find solutions to this social problem. But the study sought to investigate the potency of the church to curb and manage the prevalence of kidnapping in Ogun State Nigeria. Thus the study has recommended that should the Church engage in the following roles it will curb the problems of kidnapping:

1. The Church must teach unapologetically that people must be moved by a sense of honour, respect or dignity to avoid criminal actions. People must also be taught to think and put into consideration before taking any actions what would be the likely 
consequences of their purported actions on themselves immediate family and the society at large.

2. The church should lead the society to establish neighbourhood watch groups in towns and villages in Ogun State. These neighbourhoods watch groups whose function is to compliment the effort of the security personnel's, they are to be equipped with operational facilities so as to send messages to police to give information on security situation in their localities regarding the activities of the kidnappers. These watch groups should regularly be visiting hideouts in their areas so as to monitor the activities of the hoodlums.

3. The church should use her influence to encourage those in the decision making body of the Government to try to do something and make policies and laws that will stem down the endemic rate of poverty in the society and allow for massive creation of jobs and job opportunities as well as creating a conducive environment, so that private sectors can create jobs for the young generation. This is very necessary to shield our teeming unemployed youths from criminality.

4. The Church should also canvass for those found culpable of the offense of kidnapping to be properly brought to book. This will serve as example for others who might be thinking of going into kidnapping as means of livelihood in the nearest future. The entire respondents were of the view that if the government of the country need to equip the Police of the country well with arms and ammunitions, communication gargets and other regarding so as to have confidence to be able to combat the activities of the kidnappers.

5. The entire respondents were of the view that if the government of the country need to equip the Police of the country well with arms and ammunitions, communication gargets and other regarding so as to have confidence to be able to combat the activities of the 
kidnappers. The church should encourage those in the government to do more especially in equipping the security agencies that are at the fore front fighting crimes.

6. To prevent rural urban drift of the youths, the Church should encourage the government to develop rural areas by providing them the needed social amenities such as good road networks, pipe borne water and electricity which will make life easy for the people of the State and also create enabling environment for the development of small scale industries.

\section{References}

Abdulkabir, O.S. 2017 Causes and Incisive Solutions to the Widespread of Kidnapping in Nigeria Current Administration: Under Scholastic Scrutiny, Journal of political Science \& Public Affairs 5:258.

Abraham, U. E (2010) The Social Problem of Kidnapping and its Implication on the Socio- economic Development: A Case Study of Uyo Metropolis. A Masters Degree Thesis, Department of Sociology and Anthropology, University of Uyo, Nigeria Adebayo, S., Adeyemi, K. \&Adetayo, O. (2009). Security: Nigeria, a nation still in the woods at 49. The Punch, October 2, 54 -55 Ayantayo, J. K. (2002). "A Comparative Study of Eschatology in the

Bible and Qur'an from the Moral Perspective and its Relevance for Today" in Ado Journal of Religions Department of Religious Studies, University of Ado, Ekiti, vol. 1: 29-41.

Ayantayo, J. K. (2009). Fundamentals of religious ethics, Nigeria: End-time Publishing House.

Akinloye B., 2017. 1,000 kidnappers, robbers arrested - IG, The Punch http://punchng.com /1000-kidnappers-robbers-arrestedig/ 
Amuta, C. (2001) "Nigeria: Ethnic Militias and national Security" The Post Express, lagos, July 28. p.1

Arewa, J. A. (2013), Core National Values as Determinant of National Secuirty and Panacea for the Crime of Kidnapping and Abduction in Nigeria. Nigerian Institute of Advanced Legal Studies, Lagos, Nigeria

Asuquo, M. E. (2009). The upsurge of kidnapping and Its Influence on Public Order in Akwalbom State, Unpublished Term Paper, Department of Sociology/Anthropology, University of Uyo, Uyo, AkwaIbom State- Nigeria

Baldwin, D. A. 1997. The concept of security, Review of International Studies 23: 5-26.

Briggs, R., 2001. The kidnapping Business, The Foreign Policy Centre

Buzan, B., 2007. People, states and fear: an agenda for international security studies in the post-cold war era. Published by Ecpr Press

Del Rosso Jr. S. J.1995 The Insecure State: Reflections on "the State" and "Security" in a changing world, American Academy of Arts and Sciences and MIT press: 175-207.

Donovan, John of Royal Dutch Shell listed on its website, Nigerians Kidnap Capital Forces Shell, Chevron to Cut Outputhttp://royaldutchshellgroup.com/ 2009/02/18/Nigeria kidnap-capital-forces-shell-chevron-to-cut-output/

Ebohon, S.I; E.U.B. Ifeadi. 2012. Managing the Problems of Public Order and Internal Security in Nigeria, African Security 5(1):123.

Ehindro, Sunday, 2010. Report on capacity building A paper presented at the Retreat at the Polcie Service management and resolution for security agencies Akwa-Ibom State, Nigeria, 1 to 4 November. organized by the Institute of government and social 6. 
ENE, Warikiente Robert (2018) Kidnapping and the Nigerian society: A sociological insight International Journal of Development and Management Review (INJODEMAR) Vol. 13 No. $1 \mathrm{~J}$

Ezemenaka, Kingsley Emeka (2018). Kidnapping: A security challenge in Nigeria in Journal of Security and Sustainability Issues, 2018 December Volume 8 Number 2

Forest, J.J.F. 2012. Global trends in kidnapping by terrorist groups, Global Change, Peace \& Security 24 (3):311-330.

Investopaedia ( 2018) Conflict theory: New York

Inyag, J.D. (2006). Development: An Appraisal of Oil Exploration

Project and it Environmental Pollution on the Niger Delta

Region of Nigeria in the Journal of Global Awareness. St Johns

University Queens, New York City USA, Autumn 2006 Vol. 7,

No. 4 pp. 57-71.

Inyang, J. D., \& Abraham, U. E. (2013) The Social Problem of

Kidnapping and its Implications on the Socio-Economic

Development of Nigeria: A Study of Uyo Metropolis.

Mediterranean Journal of Social Sciences, 4(6), 531

Inyang, U. S. (2009, July 12). Kidnapping: Who Can Deliver

Nigeria? News D' OR Magazine, pp. 11-15.

Joseph, S. N.; S. M. Lynn-Jones. 1991. The Renaissance of security studies, International studies Quarterly 35 (2): 212-239.

Kara R, (2018) strain theory, Encyclopedia brittanica, Arizona pressdia (2018) conflict theory: New York

Kuril, J. 2018. Public administration for safe and secure environment: case of Slovak Republic, Entrepreneurship and Sustainability Issues 5(3): 493-501. https://doi.org/10.9770/jesi.2018.5.3 (6)

Kyrian, I. (2009). Intelligence Reports and Kidnapping. Dawn, May 17, p.9.Dzurgba, A. (2000). Principles of Ethics, Ibadan: Agape Publications, 4, Animasahun Street, Besides Teju Hospital, Off Ajeigbe Bustop, Ring road Ibadan. 
Linus C. Nnamani (2015). Socio-Economic Effects of Kidnapping in South-East Nigeria in World Journal of Management and

Behavioral Studies 3 (2): 36-43, 2015

Ngwama, J. C. 2014. Kidnapping in Nigeria: An Emerging Social

Crime and the Implications for the Labour Market in International Journal of Humanities and social Science 4(1): 133-145 http://www.ijhssnet.com /journals/ Vol_4_No_1_January_2014/15.pdf

Nwaorah, N. (2009, March 29). Are Kidnappers Worst Criminals? The Vanguard, pp. 14.

Oarhe O.; I. Aghedo. 2010. The Open Sore of a Nation: Corruption Complex and Internal Security in Nigeria. African Security 3(1): 127-147. https://doi.org/10.1080/19392206 .2010. 503854

Obasola, K. E (2015). A Critical analysis of the role of moral values as a catalyst for social and political development among people in Nigeria in Asia Pacific Journal of Multidisciplinary Research, 3, (1) 5-6

Obasola, K. E. (2013). Personal Discussion held with the Researcher. At the Religious Studies Department, of the Olabisi Onabanjo University, Ago-Iwoye on 20/03/2013

Ohakhire, A.E., 2010. "Re-positioning the Nigeria Democratic Police to meet the Challenges of Policing a Democratic Society in the 21st century and beyond A paper presented at the Retreat at the Polcie Service Commission held at Le-meridian Hotel, Uyo, Akwa-Ibom State, Nigeria, 1 to 4 November.

Okoli, A. (2008). Revealed! How Traditional Rulers Are Aiding Kidnapping in Abia. Vanguard, July 4, p. 10.

Okonkwo, C. O. (Ed.) (1980). Criminal Law in Nigeria. Ibadan: Spectrum Books Limited.

Olulowo, O.A. (2017), Socio-Ethical Perspective on the Attitude of the Church to Pre-Marital Sex among Adolescents in Lagos State Nigeria: An Unpublished $\mathrm{Ph}$. D Thesis Submitted in the 
Department of Religious Studies to the Post Graduate School in Partial Fulfilment of the Requirements for the Award of Doctor of Philosophy Degree in Christian Studies of Olabisi Onabanjo University, Ago-Iwoye, Ogun State, Nigeria.

Olulowo, Segun (2010). A Philosophical Appraisal of Job's Sufferings and its Implication to the Contemporary Christians in

Lagos State. An M.A dissertation submitted to the Department of

Religious Studies, Olabisi Onabanjo University, Ago-Iwoye

Siegel, L. J. (2002). Criminology (2nd ed.). New York, U.S.A: West

Publishing Company, pp. 82-106. Okoli, A. (2008). Revealed!

How Traditional Rulers Are Aiding Kidnapping in Abia.

Vanguard, July 4, p. 10.

Soyombo, O. (2009). Sociology and Crime: That We May Live in

Peace. The Guardian, Sept.17, pp.56-72

Syracuse university school education (2018) Theories of ethics, New

York, 32-44

Teivāns-Treinovskis, J.; Nesterova, M.; Solobutina, M.; Lipe, E. 2018. Evaluations of security measures in a legal field: ensuring public safety in the area of sexual violence, Journal of Security and Sustainability Issues 8(2) https://doi.org/10.9770/jssi. 2018.8.2 (9)

Thomas, T. and Nta, P (2009) Kidnapped and Persecuted Coman Clem's Wife, a 5 Year Old Girl, Community Pulse, August 10, p. 6.

Thom-Otuya, B. E. N. (2010). Kidnapping: A Challenge to Nigeria Security System, International Journal of Social Science, Vol. 2 No. 8, 107-116

Townsend, J (2008). Poverty and Energy: Natural Resource

Nationalism and the Natural Resource Curse. Regions No. 271

The Newsletter of the Regional Studies Association, 11-12.

Ugwu, C. I. and Chukwuma O. G. (2012) "Prayer National Security, A Study of Isaiah 58" International Journal of Theology and 
Reformed Tradition (IJTRT) 2012 Vol. 4, pp 173-190, ISSN 2141-8179

Ujumadu, V. (2009). Anambra and High Profile Kidnapping. Vanguard, October 31, p. 45.

Ukandu, I.M. (2011).The menace of kidnapping in Abia State: a study on the strategic role of religion in the amelioration of violent crimes. A thesis submitted to the department of religion and cultural studies, faculty of the social sciences, university of Nigeria, Nsukka in partial fulfillment of the requirements for the award of master degree in Religion and cultural studies

Walsh, D. and Adrain (1983). A Dictionary of Criminology London: Routledge and Kegan Paul Plc. P.45

Zeman, T.; Břeň, J.; Urban, R. 2018. Profile of a lone wolf terrorist: a crisis management perspective, Journal of Security and Sustainability Issues 8(1): 5-18. https://doi.org /10.9770 /jssi.2018.8.1(1)

Segun Ayotunde Olulowo (PhD) is a lecturer in Department of Religious Studies, University of Lagos, Akoka, Lagos State.

Solomon Taiwo Babawale (PhD) is a lecturer in Department of Religious Studies, University of Lagos, Akoka, Lagos State.

Kehinde Michael Anani is a lecturer in Department of Religious Studies, Olabisi Onabanjo University, Ayo-Iwoye, Ogun State. 